\title{
DESCRIPTION OF TWO NEW SPECIES OF HELICOID LAND-SHELLS FROM GERMAN NEW GUINEA.
}

\author{
By J. H. Ponsonis, F.Z.S.
}

Read 14th December, 1906.

\section{Rhytida Bednalli, n.sp.}

Testa depressa, tenuis, patuliformis, corneo-fusca, nitida, umbilicata ; anfr. 4 rotundati, sutura bene impressa, vix canaliculata separati, undique pulcherrime regulariter costulati et lineis nonnullis spiralibus leviter notati, ultimus rotundatus, non descendens; umbilicus apertus, infundibuliformis, usque ad apicem pervius, anfr. omnes exhibens; apertura obliqua, fere rotunda, tenuis, marginibus distantibus. Diam. maj. 7 , min. 6 mm.; alt. $3.5 \mathrm{~mm}$.; apertura 2.5 lata.

Hab.-German New Guinea.
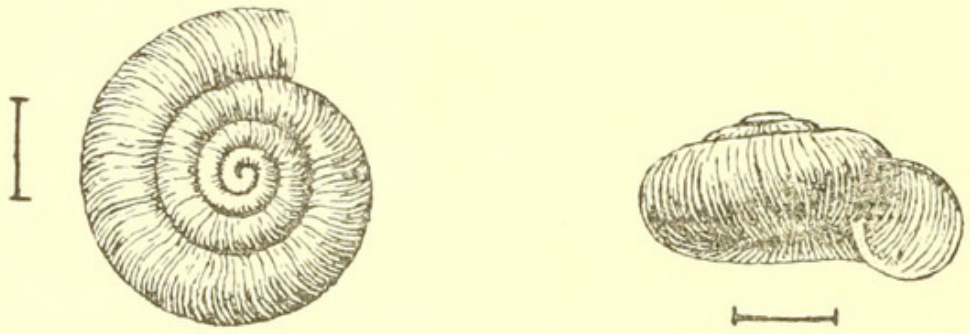

A pretty little species with rather deeply cut suture and wide perspective umbilicus. The spiral sculpture, which in reality is little more than impressed scratches, is very irregular, but here and there distinctly visible both above and below the rounded periphery.

\section{Coliolus thrix, n.sp.}

Testa elata, conico-pyramidalis, umbilicata, fusca, strigis et maculis albidis sparsim notata sub epidermide brunnea, dense longipilosa; anfractus 8-9, convexi, ultimus acute carinatus, vix descendens ; 3 primi

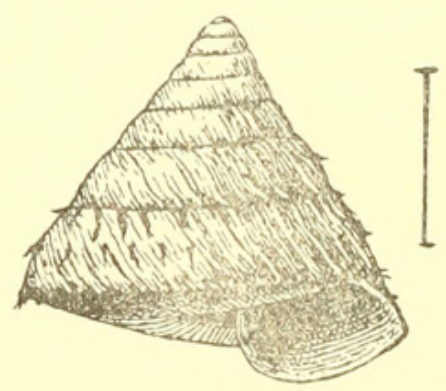

embryonales spiraliter striati, cæteri undique oblique ruditer striati, epidermide hirsuta induti, sensim a peripheria ad apicem obtusum decrescentes. Basis fere plana, medio circa umbilicum modicum 
leviter excavata. Apertura oblique ovata, marginibus distantibus, callo albo elevato junctis. Peristoma tenue, flexuosum, margine columellari brevi, vix incrassato et reflexiusculo. Diam. maj. 13, min. $12 \mathrm{~mm}$; ; alt. $13.5 \mathrm{~mm}$. ; apertura $7 \mathrm{~mm}$. lata.

Hab.-German New Guinea.

The genus Coliolus was founded by Tapparone-Canefri for C. Arfakiensis, the other known species being Canefriana, Smith, and Weiskei, Fulton. C. thrix therefore forms an interesting addition to this restricted genus, in which, judging from shell characters, it is best included. The sculpture and arrangement of the hairy epidermis resemble those features as described in C.Arfakiensis, but the shells now dealt with have only 9 as against 11 whorls, and the general form, as will be seen from the accompanying figures, is quite different. This and the preceding species were received by Mr. Bednall of Adelaide from German New Guinea, and were kindly forwarded by him to the writer for description. 


\section{$2 \mathrm{BHL}$ Biodiversity Heritage Library}

Ponsonby, J H. 1907. "DESCRIPTION OP TWO NEW SPECIES OF HELICOID LAND-SHELLS FROM GERMAN NEW GUINEA." Proceedings of the Malacological Society of London 7, 224-225.

View This Item Online: https://www.biodiversitylibrary.org/item/53746

Permalink: https://www.biodiversitylibrary.org/partpdf/202938

\section{Holding Institution}

Smithsonian Libraries

\section{Sponsored by}

Smithsonian

\section{Copyright \& Reuse}

Copyright Status: Public domain. The BHL considers that this work is no longer under copyright protection.

This document was created from content at the Biodiversity Heritage Library, the world's largest open access digital library for biodiversity literature and archives. Visit BHL at https://www.biodiversitylibrary.org. 